\title{
Corruption in Lithuania
}

\author{
Raimundas Urbonas *
}

\section{Introduction}

The negative impact of corruption on a country and its population is tremendous. It affects state politics, economics, administration, the legal and social sphere, and precipitates a negative international perception of state prestige. ${ }^{1}$ The purpose of this article is to describe the status of corruption in Lithuania in comparison with other European Union member states and other counties, discuss achievements in the creation of an anti-corruption legal framework, analyze how corruption affects democracy in Lithuania and, finally, assess corruption in Lithuania by comparing cultural conditions in Lithuania versus selected European Union countries.

Based on corruption analysis data collected by international organizations, the level of corruption in Lithuania is on the rise. More than a few international organizations performing such research have come to similar conclusions. According to data compiled by the international corruption prevention organization Transparency International, Lithuania has made some strides, but in 2008 the corruption perception index worsened, bringing it back to 2004 levels.

Ever since regaining its independence, Lithuania has created an array of legal acts designed to fight corruption; furthermore, the government's anti-corruption strategy was incited and directly influenced by the process of joining the European community. Immediately after Lithuania submitted its application to join the European Union, the fight against corruption was named its most immediate goal. As a result, Lithuania's achievements in anti-corruption programs have come to be held up as an example to

Capt. Raimudas Urbonas serves with the Second Investigation Department under the Ministry of National Defense of the Republic of Lithuania.

1 See Rupert Hodder, How Corruption Affects Social and Economic Development: The Dark Side of Political Economy (Lewiston, NY: Edwin Mellen Press, 2007); Susan Rose-Ackerman, Corruption and Government: Causes, Consequences, and Reform (Cambridge: Cambridge University Press, 1999); Leslie Holmes, Rotten States? Corruption, Post-Communism, and Neoliberalism (Durham, NC: Duke University Press, 2006); William L. Miller, Åse B. Grødeland, and Tatyana Y. Koshechkina, A Culture of Corruption? Coping with Government in Post-Communist Europe (Budapest: Central European University Press, 2000); Susan Rose-Ackerman, International Handbook on the Economics of Corruption (Cheltenham, U.K.: Edward Elgar, 2006); Martin J. Bull and James L. Newell, eds., Corruption in Contemporary Politics (New York: Palgrave Macmillan, 2003); Rasma Karklins, The System Made Me Do It: Corruption in Post-Communist Societies (Armonk, NY: M. E. Sharpe, 2005); Stephen Kotkin and Andras Sajo, eds., Political Corruption in Transition, A Skeptic's Handbook (Budapest: Central European University Press, 2002); and Donatella Della Porta and Alberto Vannucci, "Corruption as a Normative System," paper prepared for the conference "Corruption Control in Political Life and the Quality of Democracy: A Comparative Perspective, Europe-Latin America,” CIES-ISCTE, 19-20 May 2005. 
other countries attempting to join the European Union. In 1999, Transparency International was invited to establish an office in Lithuania, which it did in 2002. Furthermore, in 1997 a Special Investigation Service under the Ministry of Internal Affairs was created, and in 2002 the agency acquired complete administrative independence, answerable only to the President of Lithuania and the Seimas (the Lithuanian Parliament). As part of the wider Lithuanian strategy to combat corruption, the nation ratified a range of international conventions, created a national anti-corruption strategic plan, made changes to its public administration and public procurement organization, and implemented an array of legal acts and amendments. All institutions involved in the implementation of the national fight against corruption had a role to play in the execution of Lithuania's long-term anti-corruption strategy. A discussion of the legal framework of these anti-corruption efforts is introduced in the second part of this essay.

However, it must be noted that even a well-prepared legal base in itself does not begin to have effect until its mission is executed not on paper or in public declarations, but through real action. International monitoring reports state that Lithuania's anti-corruption strategy is comprehensive, but that its execution is open to criticism. Although efforts to implement anti-corruption policies on the ground have been intensive, the tangible results have been very few in number. As a matter of fact, the rate of corruption in Lithuania is not only decreasing, but, according to the latest data, is on the rise. This fact is ultimately attributable to the established governmental tolerance of corruption, the judicial system's inability to act, abuse of power among government officials, low standards of living across Lithuanian society, and stagnant expectations of what is considered acceptable in the community. According to Transparency International data, as many as 75 percent of Lithuanians believe that bribes help solve problems, and as many as 65 percent are willing to give a bribe in order for their "business" to be handled in a "better" manner.

Given the prevalence of such values in the community, it is hard to expect a different attitude towards corruption from politicians and other government officials. In Lithuania, extremely important economic or political decisions affecting the entire nation are made by several influential individuals who manage to control the highestranking politicians and government officials. This article presents opinions of former and current high-ranking governmental officials, politicians, public figures, and journalists regarding the political situation in Lithuania, as well as their attitude regarding the state of democracy and corruption as a threat to statehood. It is noted that a small, influential circle can protect their political and economic interests by sacrificing the general standard of living, which can ultimately lead to the effective takeover of the state. The challenge posed by corruption to democracy and the rule of law in Lithuania will be discussed in further detail below.

Corruption is not only a curse of nations emerging from former totalitarian rule; it is also considered to be an inevitable trait of modern society. The scholarly literature describes various attempts to fight corruption at all costs in many different nations and cultures. However, with the exception of Hong Kong, not a single country anywhere in the world can boast tangible results. Methods of fighting corruption will remain mere 
lists on paper as long as there is insufficient political will and desire to rid public life of corruption, and until the citizenry itself is ready to reject corrupt relationships in all spheres of society. The final section of this article will discuss the challenge of confronting corruption as a component of public culture.

\section{Corruption in Lithuania in the International Context}

According to Transparency International's 2009 Global Corruption Barometer, 30 percent of Lithuanians admit that they or their family members have given a bribe in the previous twelve months. This is the highest index among the researched European Union (EU) countries, and one of the highest indices in the world. The Global Corruption Barometer is a sociological study commissioned by the Transparency International secretariat, for which over 73,000 residents of sixty-nine countries around the world were questioned about the level of corruption in their societies. The goal of the study was to determine public opinion towards state institutional corruption and its degree of severity. Lithuania was included in the Global Corruption Barometer study for the fourth time in 2009. The results of the study indicate that bribery remains a serious problem in Lithuanian society. According to the results of the 2007 study, the corruption index in Lithuania amounted to 29 percent. Based on the 2009 study, Lithuania found itself in the same group with such countries as Armenia, Azerbaijan, Bolivia, Cambodia, Ghana, Indonesia, Iraq, Kenya, Moldova, Russia, Senegal, and Venezuela.

These barometer numbers essentially mirror the 2008 Lithuanian corruption survey results released by the Lithuanian office of Transparency International, which indicated that 24 percent of Lithuanians admitted to having given a bribe in the previous twelve months. Lithuanians seem to be some of the world's most vocal critics when it comes to assessing their government's efforts to curb corruption. When asked to assess the effectiveness of their government's anticorruption initiatives, Lithuanians were especially critical -84 percent of the respondents believe that government efforts to curb corruption are ineffective, and only 3 percent believed them to be effective. Out of all sixty-nine countries surveyed, only residents of Israel have a lower opinion of their government's anticorruption efforts (86 percent negative). As compared with other EU countries, Lithuanian citizens especially emphasize the incidence of corruption among civil servants, courts, and legislative institutions, with 27 percent of Lithuanians believing that civil servants are the most corrupt sector of society. Even more grim assessments of civil service corruption among EU countries came from the Czech Republic (40 percent) and Poland ( 31 percent). Lithuanians held only a slightly less gloomy view of their judicial and legislative systems, with 23 percent of Lithuanians rating the courts and the Seimas most corrupt, respectively. Bulgarians have a more jaundiced view of their judicial system (38 percent), while Romanians are less trusting of their parliament (33 percent). According to the Lithuanian office of Transparency International, the 2009 Global Corruption Barometer clearly indicates the gap between 
the Lithuanian public's expectations and the actual measures and results of the Lithuanian government and public sector representatives' anti-corruption efforts. ${ }^{2}$

Globally, Transparency International's Corruption Perceptions Index (TI CPI) is one of the most important global corruption perception studies, offering a panoramic picture of how different countries around the world manage to control corruption, assessing the situation on a scale of 0 to 10 , where 0 indicates a completely corrupt country, and 10 indicates a highly transparent country. Assessing general corruption levels in different countries using practical data is very complex, for example, when it comes to comparing the number of bribes, criminal prosecutions, court rulings, or corruption scandals. Such comparisons do not show the true level of corruption; instead, they merely indicate the quality of criminal prosecution, or the level of corruption disclosure in the media. For that reason, a more reliable means of situational assessment would be to use native experience and perceptions expressed by the people who are directly affected by corruption-related issues in their own country.

TI CPI findings are sometimes criticized for depicting corruption perceptions within only a limited segment of society (e.g., businessmen and experts). The index is also criticized for reflecting only perceptions, rather than the actual level of institutional corruption. According to the 2007 corruption perceptions map data, the Lithuanian public saw multiple facets of the problem. Both residents and business executives did not see corruption as the most important problem affecting Lithuanian society and business development. However, corruption was perceived as a problem by a relatively large cross-section of society. Corruption was perceived as being "very serious" or "serious enough" by as many as 90 percent of the residents, and 65 percent of business executives. Such assessments can be explained by the fact that corruption is a chronic disease in public life, which, upon evaluation, gives way to such related problems as inflation and road safety. At the time of the survey, Lithuania was being shaken by the ripple effects of corruption, with corruption being discussed as the root cause of a wide range of problems that were at the forefront of public discourse. Based on the businessmen's assessments, it should be noted that, in the broader context, corruption appears to be a derivative problem, arising from direct business dissatisfaction with red tape, legal loopholes, multiple regulatory bodies, or dishonest competition. ${ }^{3}$

Lithuania's score in the 2008 TI CPI study was 4.6 points, leaving it in $58^{\text {th }}$ place out of 180 countries participating in the study. TI determines their index score based on two years of data from various sources. Thus, the 2008 CPI study encompasses data from 2007 and 2008. ${ }^{4}$

2 See "Lietuviai - tarp kyšininkavimo lyderiu,", on the website of Transparency International's Lithuania office, at www.transparency.lt/new/index.php?option=com_content\&task=view\& $\mathrm{id}=10895$ \&Itemid $=24$.

3 See www.stt.lt/documents/soc_tyrimai/korupcijos_zemelapis_2007.pdf.

4 See "Lietuva tampa Baltijos šaliu autsaidere;" available at www.transparency.lt/new/index. php?option $=$ com_content\&task=view\&id=10856\&Itemid $=25$. 


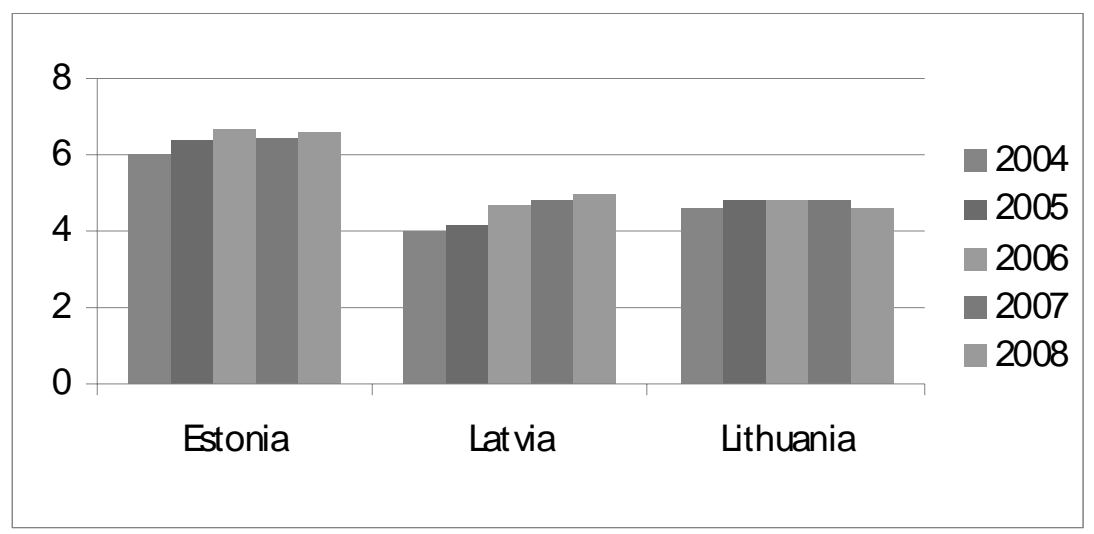

Figure 1: Transparency International's Baltic Corruption Perceptions Index Results, 2004-08.

TI also presented a Baltic Corruption Perceptions Index for 2004-08, which showed that Lithuania, in terms of its CPI score, gave up its position among the Baltic States and became an outsider (see Figure 1). While in 2004 Estonia's CPI score was only 6, by 2008 it had reached 6.6. Latvia's CPI score showed annual growth from 4 in 2004 to 5 in 2008. In the meantime, Lithuania's score in 2004 was 4.6, followed by three years of stability after reaching 4.8. However, 2008 showed a slight (but still worrisome) drop in Lithuania's CPI score to 4.6.

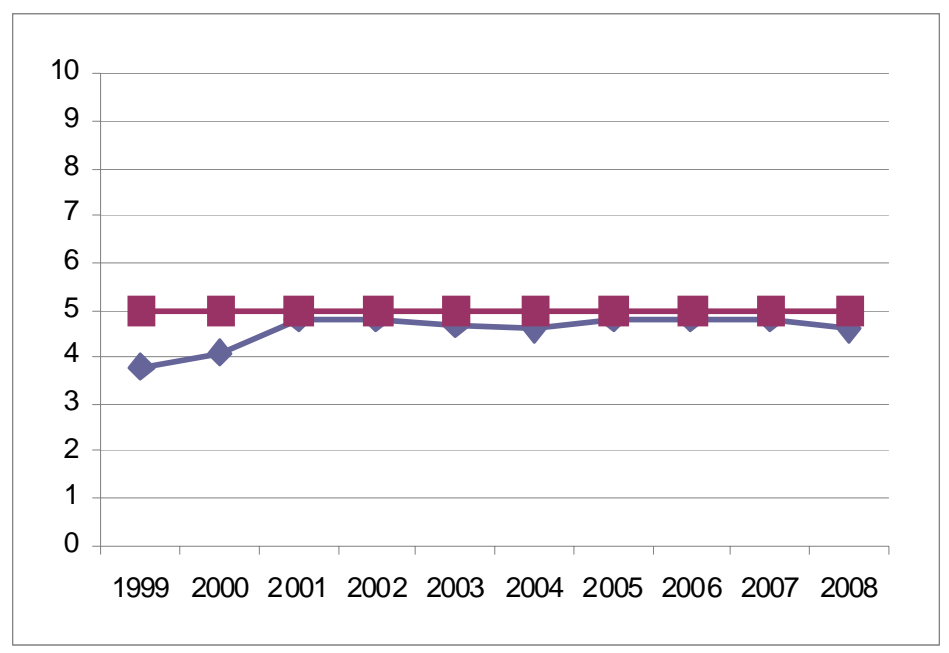

Figure 2: Lithuania's Corruption Perceptions Index Results, 1999-2008.

( $5=$ threshold for severe corruption problems $)$ 


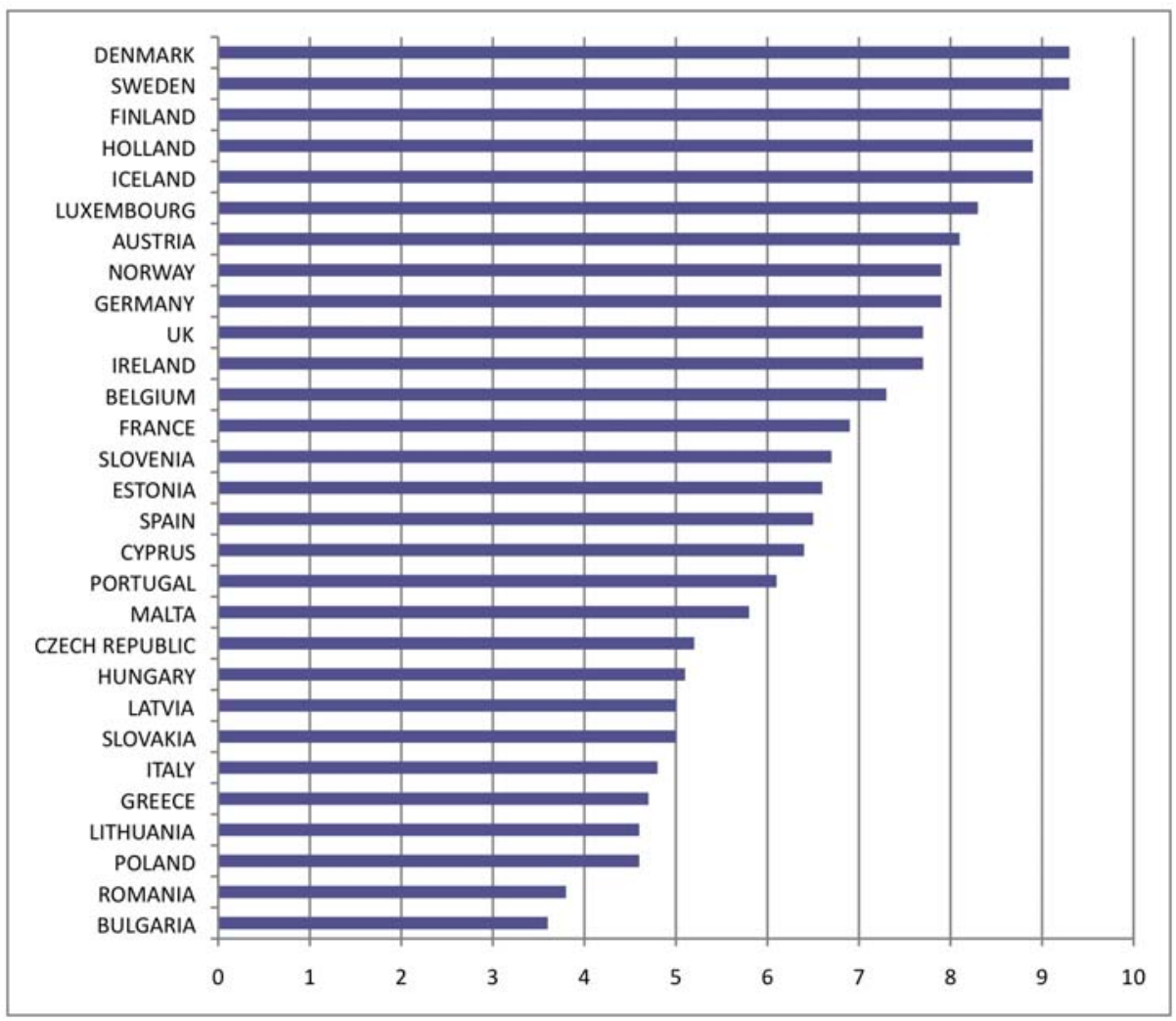

Figure 3: 2008 Corruption Perceptions Index Results for EU Members and Other European Nations.

It is generally accepted that countries whose CPI scores do not go over 5 points encounter severe problems related to corruption. Changes in the Corruption Perceptions Index scores from 1999-2008 among post-communist new members of the European Union show a decreasing tendency among only two countries: Hungary and Lithuania. However, in Hungary the index did not drop below 5 (it currently stands at 5.1), while Lithuania's score fell from 4.8 to 4.6, leveling with Poland's score, which had increased from 4.2 (see Figure 2).

In terms of Lithuania's CPI in relation to other European countries, Lithuania and Poland share twenty-seventh place. Lower scores are registered in Romania (3.8) and Bulgaria (3.6), while the leaders on the list are Denmark and Sweden with 9.3 points (see Figure 3). ${ }^{5}$

5 See Transparency International's Corruption Perceptions Index results for 2008, at www.transparency.lt/new/images/ti_ksi_2008_galutine.pdf. 
The measurements that factor into the index reflect respondents' opinions and attitudes regarding the level of corruption in their respective societies, as well as its role in public life. Opinion polls, discussions, and in-depth interviews are conducted with representatives of the elite-including businessmen, government officials, specialists, and experts - as well as with members of the general public. According to the noted corruption analyst Michael Johnston, corruption perception studies are significant, and can affect foreign policy, aid, foreign direct investment, and crucial governmental decisions. They can also induce certain political processes, especially in the area of democratization. However, one should not forget that even though the results of these studies are publicly available, the seemingly positive benefits of such studies may also be deceptive. ${ }^{6}$

In terms of elite groups, it should be noted that, although it can be extremely difficult to carry out opinion research and opinion surveys among a nation's elite-who are guarded about sharing their opinions, for a wide range of reasons - such research remains very important and useful. The elite are usually a small group of citizens in charge of the state's decision-making processes. State institutions' effectiveness in implementing anti-corruption initiatives as well as reforms in other sectors depends on the elite's ability and interest in understanding and acknowledging problems related to corruption, and on the depth of their political will to resolve them. Unfortunately, one can find only a few recent examples of opinion research among elites in transitional states. A group of political scientists from the University of Oslo performed a study in order to determine Latvian, Lithuanian, Estonian, and Russian elites' perceptions of democratization and market liberalization by using a structured interview method. Among survey respondents in each country were members of the parliament, ministry leaders, state officials, and representatives from the business community, the judicial system, municipal governments, and cultural institutions (media, education, and art). The results showed that the elites in these post-communist countries viewed corruption as a significant problem worth considerable attention. Survey results also revealed that Estonia was experiencing fewer corruption problems than Latvia, Lithuania, or Russia. ${ }^{7}$

Lately, there has been an abundance of debate among researchers as well as public officials regarding corruption diagnostics instruments and their significance. According to the Transparency International source book, research and other diagnostic measures serve as important tools in the corruption reduction process. They may contribute to institutional reforms, stimulate debates on specific hot issues, expose problems and priorities for reform execution, give the community a "voice," and strengthen local property rights. Based on the Lithuanian example, we may find at least two sides of this issue, one positive and one negative.

First, the positive side. As the Lithuanian example has shown, multi-national comparative research may significantly contribute to the analysis of corruption and its root

6 Jolanta Piliponyte, "Instruments and Challenges of Corruption Diagnostics Around the World and in Lithuania," Sociologija: Mintis ir Veiksmas [Sociology: Thought and Action] 1 (2006): 101; available at www.ceeol.com.

7 Ibid. 
causes, and can further additional in-depth studies in the specific countries. As a result, loopholes in public administration can be uncovered and institutions that are heavily affected by corruption can be exposed, thus contributing to the implementation of anticorruption policies.

But the other side of the issue offers a less rosy outlook. Making the results of corruption research public is a relatively sensitive process, especially on the institutional and municipal levels. Even on the international or national levels, complex corruption indices and measures of diagnostics invite different interpretations of results, and can lead to misunderstandings. This, in turn, may create tension between project researchers and their clients, between researchers and politicians, and between different interest groups. Furthermore, it may cause victimization of both corruption research participants and related focus groups. ${ }^{8}$

Analysis and assessment of corruption levels and their expansiveness must take into account the political, economic, social, cultural, and national context, as well as consideration of the way in which information involving disclosures of corruption incidents is going to be presented. These factors affect all research results, which should not be evaluated and accepted as the absolute truth. The Special Investigation Service of the Republic of Lithuania presented an example of such variable interpretation:

[F]oreign experts note, that corruption in Lithuania is on the rise.... Such opinion is prevailing due to the fact, that this is how we represent ourselves, ... even though in the developed countries [the rate of corruption] is much higher, no one talks about it. ... In Germany alone in one week five hundred criminal cases were initiated against doctors, because they took money from pharmacy companies and pushed their product.... If this ever happened here, public reaction would have been much louder, while over there it all went away very quietly. ${ }^{9}$

\section{Progress Toward Combating Corruption in Lithuania}

Lithuania expressed its resolution to become a member of the European Union on 12 April 1995 by signing an agreement establishing an association between the European Communities and their member states and the Republic of Lithuania. Lithuania ratified this intention by the end of the same year by filing an official application to join the European Union. Upon ratification and enactment of this agreement, the coordination of its legal framework with European standards became not only a general trend in the implementation of legal reforms, but also Lithuania's international obligation to the European Union and its member states.

Among Lithuania's assumed obligations in this regard were the preparation and implementation of laws governing the responsible institutions' roles in anti-corruption efforts. Corruption in prospective EU member states was one of the European Commission's primary worries. As a result, the European Commission repeatedly expressed

Ibid., 109.

9 See "Pavojingiausia-politine korupcija," Straipsniai.lt (28 May 2005); available at www.straipsniai.lt/korupcija/puslapis/8731. 
its concern regarding corruption levels in the candidate states and emphasized that progress toward combating corruption was the chief task to be executed by all candidate states in order for them to meet European Union membership requirements. Still, as was noted by the Open Society Institute in their EU Accession Monitoring Program, according to 2002 analysis,

The Commission's evaluation of corruption levels in candidate states was problematic not only due to the fact that Central and Eastern European countries face corruption problems different from those encountered by EU member states, but also due to the fact that European Union itself still has no clear anti-corruption framework. As a result, the European Commission did not set any clear corruption and anti-corruption politics standards for the candidate states. ${ }^{10}$

The political criteria that candidate states would have to meet in order to become members of the EU were laid out at the 1993 European Council in Copenhagen. This Copenhagen Mandate allowed the Commission to require of candidate states the implementation of anti-corruption acts that had not been implemented by the member states themselves. An example illustrating the difference between the Commission's conditions as applied to member states and candidate states is the European Union Criminal Law Convention regarding corruption. The Commission kept putting pressure on member states to sign and ratify the Convention, as a result of which eight out of ten member candidates ratified the Convention before June 2002, while only three out of fifteen European Union member states followed suit. This gave the impression that a double standard existed for the candidate states as opposed to the member states. ${ }^{11}$

In spite of the European Union institutions' inconsistent attitude towards anti-corruption efforts for member states versus candidate states, Lithuania, as a candidate state, successfully created an effective anti-corruption legal framework. Criminal justice framework components were adopted, and legislative amendments and supplements were put in place, including changes to the Code of Administrative Infringements, the Civil Code, the Criminal Procedure Code, and the Operational Activities Act. In addition, the Law on the Restraint of Organized Crime was passed, outlining legal accountability for corrupt activities. A number of other laws dealing with anticorruption measures have been adopted as well, including:

- Law on Declaration of the Property and Income of Residents

- Law on the Adjustment of Public and Private Interests in the Public Service

- Law on Public Procurement

- Law on Public Administration

- Law on Civil Service

10 EU Monitoring and Advocacy Program, "Monitoring the EU Accession Process: Corruption and Anti-corruption Policy" (2002); available at www.eumap.org/reports/2002/corruption.

11 Stojimo i ES stebésenos procesas: korupcija ir antikorupcine politika (Vilnius: Open Society Institute, 2002), 13. 
- Law on the Prevention of Money Laundering

- Law on the Accounting of the Lawful Acquisition of Personal Property and for the Origin of Income

- Law on Competition

- Law on Lobbying Activities

- Law on Control of Funding of Political Campaigns

- Law on Funding of Political Parties and Political Organizations

- Law on the Special Investigations Service.

The Seimas and the government adopted a number of anti-corruption laws outlining specific measures for fighting corruption. One of the most significant of them is the National Anti-Corruption Program of the Republic of Lithuania, which was ratified in January 2002 and laid out a course of action for the next five years. The program has been updated and approved by a parliamentary resolution in 2009 , with an action plan outline for 2009-10.

The purpose of the National Anti-Corruption Program is to assure a long-term, effective, and focused corruption control and prevention system in Lithuania. While supplementing the program, particular focus was placed on the elimination of shortcomings identified during the previous phase of program implementation, as well as on more effective preparation of execution plans. During the preparation phase, consideration was given to a set of recommendations submitted by the National Audit Office of Lithuania in their report regarding the 2002-07 phase of the National Anti-Corruption Program, as well as recommendations proposed by the parliamentary Anti-Corruption Commission and Audit Committee. The draft of the program was coordinated with state and municipal institutions; it was also published on the Special Investigations Service website, and was accessible to everyone willing to express their opinions or suggestions.

The National Anti-Corruption Program strategy consists of three elements: corruption prevention, investigation of corruption-related offenses, and raising public awareness of anti-corruption efforts. Specific strategic means were defined for program implementation, and specific goals and assessment criteria were set, which would in turn alleviate continuous monitoring of execution and ensure objective reciprocal connection. Most of the program's strategies focus on corruption prevention in efforts to improve administrative and public services in electoral government, customs, health care, construction, environmental management, and public procurement. The National AntiCorruption Program strategy is developed, organized, and controlled by the government, with the participation of the Special Investigations Service. The program is funded by state and municipal funds, but there are no provisions in place for separate financing.

Another crucial legal act - the Law on Prevention of Corruption-was adopted in May 2002. This law mandates that, in addition to the National Anti-Corruption Program, other institutional anti-corruption programs should also be implemented by state 
and municipal institutions. All relevant institutions are required to develop such programs, taking into account suggestions made by the Special Investigations Service. Also, for the purposes of implementing this law's requirements for corruption prevention measures, institutions have the right to establish separate divisions or assign personnel responsible for corruption prevention within the institution itself. Furthermore, this law regulates the provision of information about persons seeking or holding positions at a state or municipal institution (Article 9) by requiring that the information be provided to the head of the institution or state politician in efforts to assure that state and municipal employees have only the highest reputations. This background check information on people seeking government employment is furnished by the Special Investigations Service, which, based on the submitted and collected information, is authorized to commence their investigation according to the provisions of the law.

The Criminal Code of the Republic of Lithuania determines penalties for criminal offenses against state offices and the public interest, such as bribery, bribery through an intermediary, subornation, malfeasance, unlawful registration of property rights, and failure to perform office duties. This law applies to state politicians, civil servants, and other individuals of similar status. ${ }^{12}$

The purpose of the Law on the Adjustment of Public and Private Interests in the Public Service (adopted in 1997) is to clarify and regulate the intersection of the private interests of persons employed in public service and the public interests of the community, ensuring that holders of public office should make decisions solely in the public interest, in an entirely impartial manner, without consideration of their own interests. This law is a crucial element in preventing the emergence and spread of corruption in the public service. ${ }^{13}$ According to the law, "public interests" mean the public's expectations with regard to impartial and just decision making on the part of the persons in public office. Individuals holding public office must declare their interests by filing a declaration of private interests, including business concerns and partnerships, real estate holdings, stocks, etc. The declaration must be submitted to the head of the institution in which the individual is employed within one month of the individual's election or appointment to the office. The law demands that the declaration contents, if unchanged, must be confirmed in writing on a yearly basis. If there are any changes in the declared data after the filing of the declaration, the public servant must declare the changes within two weeks from the day the changes in the data occurred, and immediately in the event of new circumstances that might result in a conflict of interest. ${ }^{14}$ The private interest declarations of state politicians, state officials, judges, chairpersons and deputy chairpersons of parliamentary political parties, and a number of other state officials are made available to the public. The data are published by the Chief Official Ethics Commission, which monitors adherence to the law. The nature of the Law on the Adjustment of Public and Private Interests in the Public Service is, in

12 The Republic of Lithuania Criminal Code, Chapter 33.

13 Republic of Lithuania Law on the Adjustment of Public and Private Interests in the Public Service, No. VIII-371 (1997).

14 Ibid. 
essence, preventative. That is, in order to determine whether a violation of this law has occurred, it is not necessary to find that the official realized his/her private interests at the expense of the public interest. It is sufficient to find that the official failed to take the measures prescribed by the law to avoid any conflict between public and private interests in his/her activities, i.e. that the official failed to fulfill his/her duty of self-exclusion from participation in the preparation, consideration, or passing of decisions which might give rise to a conflict of interest situation as defined in Article 11 of the law. ${ }^{15}$ Violation of the Law on the Adjustment of Public and Private Interests in the Public Service also violates ethics principles of the state official's duties and activity. Violation of the requirements of the law is considered to be a gross violation of their office.

The Chief Official Ethics Commission (COEC) is an institution specifically established on the basis of the provisions of the Law on the Adjustment of Public and Private Interests in the Public Service. Its purpose is the oversight of adherence to the law. For purposes of achieving these goals, as well as the execution of related tasks, COEC has supreme competence, which, in cases of competition with other institutions' areas of responsibility, has first priority. The COEC's right to enforce the provisions of the Law on the Adjustment of Public and Private Interests in the Public Service may not be restricted or limited by acts or lack of action by other institutions in this legal area. ${ }^{16}$ When systematically assessing the scope of the COEC's authority as defined by legal acts, as well as the importance of adherence to the standards in public service control as laid out in the relevant legislation dealing with efforts to maintain democratic state administration, it is notable that the COEC has the authority to make recommendations to a respective institution or official, and to issue an official penalty to individuals it finds to be in violation of the Law on the Adjustment of Public and Private Interests in the Public Service. ${ }^{17}$

Another significant legislative measure in the fight against corruption is the Law on Public Procurement, which was first adopted in 1996 and has been amended and perfected many times since in order to adjust its contents to the requirements of the European Union. Equally important is the fact that public procurement in Lithuania has been conducted in accordance with general regulations and commonly accepted principles of equality of rights, non-discrimination, and transparency. The main requirements of the relevant law for persons executing acquisition procedures - such as "confidentiality guarantee," "impeccable reputation," and "declaration of impartiality"-are directly related to anti-corruption provisions. An annex to the law, newly ratified on 15 September 2008, lists ten European Union legal acts that have been implemented by

15 Lietuvos vyriausiojo administracinio teismo $2007 \mathrm{~m}$. lapkričio 26 d. sprendimas administracineje byloje, Nr. A14-844/07.

16 Lietuvos vyriausiojo administracinio teismo $2003 \mathrm{~m}$. kovo $6 \mathrm{~d}$. nutartis administracineje byloje, Nr. A11-222-03.

17 Lietuvos vyriausiojo administracinio teismo $2004 \mathrm{~m}$. rugpjūčio 25 d. nutartis administracinèje byloje, Nr. A5-706/2004. 
virtue of the law's passing. ${ }^{18}$ Lithuania's Public Procurement Office monitors adherence to the provisions of the law during all phases of public procurement. The regulations of the Public Procurement Office authorize the initiation of administrative proceedings against individuals who are found to be in violation of the Law on Public Procurement. Upon establishing violations of the law or possible manifestations of corruption, the Public Procurement Office has the right to refer the matter to law enforcement agencies for further investigation. ${ }^{19}$

Based on the assessment made by Lithuanian and foreign experts, public procurement belongs to the sphere of activity that lends itself to the possibility of corruption and other illegal activities. For that reason, the fight against corruption continues to be the main focus of attention with respect to procurement activities. The anti-corruption program and action plan prepared by the Public Procurement Office provide consistent help in the fight against corruption by reducing the occurrence of corruption in public procurement. The most significant and effective measures of the fight against corruption are the prevention of violations of the Public Procurement Law and stricter control over public procurement. In both 2006 and 2007, between twenty and thirty individuals were charged with administrative penalties for infringement of the Law on Public Procurement. In the same period, twenty-six public procurement documents were submitted to the Special Operations Service, and thirteen public procurement documents were handed down to the prosecutor's office for investigation. ${ }^{20}$

After conducting the assessment of corruption's effects on the nation's social and economic development while implementing the 1997-2000 Government Action Plan, and taking into account international obligations, ${ }^{21}$ in 1997 the government of the Republic of Lithuania decided to establish a separate institution that would be responsible for the fight against corruption. The main task entrusted to the Special Investigation Service (STT) under the Ministry of Interior was to reduce the state's exposure to corruption. Although at the outset of its activity the STT initiated a large number of proceedings in connection with corruption-related offences, it seemed apparent that law enforcement efforts to detect and investigate isolated offences were insufficient; it would also be necessary to analyze and investigate the entire system of public administration in order to eliminate opportunities for corrupt practices. This analysis of anticorruption activities was followed by a decision to expand the STT's functions and entrust the Service with the development and implementation of corruption prevention measures. Moreover, the Service was severed from the Ministry of the Interior in order to ensure the utter impartiality of its activities, and it was granted the status of an independent institution. In 2000, STT became an institution independent from the executive branch, accountable only to the President and the Seimas. The main areas of STT

18 See http://www.viesiejipirkimai.eu/lietuvos-respublikos-vie-j-pirkim-statymas-aktuali-statymoredakcija-nuo-2008-09-1/.

19 See www.vpt.lt.

20 See http://old.lrv.lt/14_vyr_dok/min-planai/2008_strat_plan_istaigos/Pirkimu.pdf.

21 In 1995, Lithuania ratified the Council of Europe Convention of 8 November 1990 on Laundering, Search, Seizure and Confiscation of the Proceeds from Crime. 
activity include criminal prosecution, corruption prevention, and anti-corruption education and promotion of public awareness. The STT also conducts anti-corruption assessments of legislation in areas that are particularly prone to corruption, and presents conclusions as to how it may be improved. The STT determines whether or not state and municipal offices create opportunities for corruption and abuse of office, and provides actionable conclusions and proposals. It also monitors the implementation of the measures of the National Anti-Corruption Program, prepares methodologies for corruption probability assessments, and analyzes possible signs of corruption. The STT encourages the public to actively fight against corruption by reporting potential effects of corruption in the public sector and by not encouraging bribery through personal actions. The STT has taken the initiative in this struggle, and is making every effort to enable Lithuania to move into the ranks of states with low levels of corruption. ${ }^{22}$

The legal framework of anti-corruption measures in Lithuania appears to be relatively comprehensive and multifaceted, and is considered to be exemplary among the new EU members. However, the most perfectly prepared legal framework will not guarantee effective implementation of ethics standards in the fight against corruption. Only when the attitudes towards corruption among the public and the legislators begin to coincide will we be able to expect effective public support and governmental contributions in the fight against corruption. A number of laws and legal acts have been adopted granting Lithuania's citizens the chance to participate and affect the decisions of government officials. However, most of these measures simply have not worked. ${ }^{23}$

\section{Corruption as a Challenge for Democracy}

The disease of corruption infects old democracies and authoritarian regimes alike, but young democracies are not immune from it either. In the post-Cold War era, political processes and state control in such societies began to depend heavily on spheres of private interests, while the sudden poverty experienced by many residents in these transitional states created deep internal social conflicts and contradictions. Poverty, poor health, continuous reductions in life expectancy, and uneven distributions of income and wealth were all taken to be signs of corruption. In Lithuania, aside from regularly occurring incidents of bribery, much more complex forms of abuse of public offices and other political corruption took place, and were extremely difficult to monitor. To-

22 See www.stt.lt/.

23 See Jolanta Palidauskaite and Aušra Vaisvalavičiūtè, "Antikorupcinio švietimo Lietuvoje svarba," available at www.smf.su.lt/documents/konferencijos/Galvanauskas\%202005/2005 $\% 20 \mathrm{~m} . \% 201$ leidinys/Palidauskaite_Vaisvalaviciute.pdf. 
day's result is a democratized society with one of the world's highest suicide rates ${ }^{24}$ as well as an astounding rate of emigration. ${ }^{25}$

A 2003 article in Der Spiegel started its analysis of corruption in post-communist countries with the Lithuanian example. According to the article, while post-communist countries ran according to a political model where "one hand washes the other," there was an increasing alienation between the citizens and their democratically-elected government according to the principle, "the state is [made up of] those above us, hence they are our enemies. ${ }^{26}$ Such an attitude was inherited from the communist times, and still retains its vitality.

The focus of the Norwegian political scientist Sven Arne Lie's research is democracy development in Eastern European countries. Although his interest is in democratization tendencies among post communist-countries more generally, he has primarily focused on Lithuania. During a 2007 interview with the newspaper Lietuvos zinios, he noted:

Evidently, your politicians have little clue of what the democracy is about. Such a political handicap affects decision-making. After all, the biggest value of democracy is the fight of ideas. Your biggest problem is the fact that you do not have a single party that would represent [the] interests of a specific group in the society. Your parties will rather rely on their leaders and fulfill interests of respective financial groups. It is obvious that interests of Lithuanian people have no place in this political system. No one will deny that Lithuania is a democracy; however the quality of its democracy is particularly poor, political system is corrupt, and there is no internal party control. Corruption in Lithuania is more noticeable than in other countries. Due to the internal political organization control weakness, it is easy to buy interest protection through bribery. It is Lithuania's misfortune that people's opinion has no influence over politicians' decisions. ${ }^{27}$

Interestingly, low levels of democratization and corruption of the political system are mentioned in both examples. The purpose of this section of the essay is to present in their own words the opinions of well-known Lithuanian figures - politicians, public activists, political scientists, and journalists - regarding the state of democracy in Lithuania and how it is affected by flourishing corruption.

24 There were 42 suicides per 100.000 people in Lithuania in 2003, compared to 38.5 per 100,000 people in 2005. Data available at www.savizudybes.lt/vidinis.asp? $\mathrm{DL}=\mathrm{L} \&$ TopicID $=$ 12.

25 According to Statistics Lithuania data, 447,000 Lithuanian residents have emigrated since 1990 (this figure assesses both declared and undeclared departures). Data available at www.stat.gov.lt/lt/news/view/?id=1927; Stanislovas Kairys, "Lietuvoje siauteja visas pokomunistines šalis kamuojanti epidemija," Straipsniai.lt (27 July 2004); available at www.straipsniai.lt/korupcija/puslapis/6354.

26 Marion Kraske, Christian Neef, and Jan Puhl, "Boom in Bakschikistan," Der Spiegel (15 December 2003).

27 Sven Arne Lie, "Lietuvoje šlubuoja demokratija," Lietuvos zinios (30 July 2007); available at www.bernardinai.lt/index.php?url=articles/ 65775 . 
Kestutis Cilinskas: Attorney, defender of human rights, public activist, chair of the Board of the Human Rights Monitoring Institute, member of the Seimas from 2007-08

The Communist regime was created by breaking the Western legal system. In the USSR Constitution, this regime even defined the superiority of the Communist Party's ideology over the rule of law. In cases where the rule of law is inferior to politics and politicians, the state of civil rights and freedoms is predetermined by politics and not law. With the resolution of emancipation, new problems appeared: the effects of the failed shadow economy, the so-called "marauders" - individuals who during the years of independence and the confusion related to the creation of a free economy ransacked millions and billions, leaving behind bankrupt enterprises and insolvent banks. Having taken this path to the free market, money and the idea of getting rich became the main goals in society. As a result, with no legal framework to stop it, government structures were filled with business moguls. Rather than relying on the help of the politicians they supported, they wanted to have direct access to power in order to get instantly rich. This way is cheaper and more reliable. When the idea of instant wealth rules over law, then even with standard democratic laws in place, and with the acceptance of every possible European Union law, the country still remains more of an oligarchic democracy than a democracy with the rule of law. When trying to determine whether the rule of law and human rights protection in Lithuania is possible, we encounter a very complex situation. We live in a time when the highest post in the country is taken by business moguls who demonstrate their contempt for the rule of law and human rights and civil equality before the law. After their election, they haggle for public offices that would allow preferential access to European Union funds. Using their acquired influence, such government representatives-businessmen slow down the normal rate of business development, because the natural interest of their protected business or business groups lies in reducing their competitors' chances to establish themselves. Businesses that give profit to public officials directly or through their spouses or other individuals may thus exercise their superiority in public procurement or when participating in European Union fund appropriation. Since the duties of the so-called oligarchs or business moguls in high offices are also an avenue toward increased profits in their business, they are determined to fight anything that would threaten to reduce their influence in the government. Publicity and criticism of their activities, among other things, affect their ability to exert influence. That is why such government officialsbusinessmen usually thwart any likelihood of publicity and criticism, and persecute those who express such criticism.

When the judicial system depends on political power, such persecution for criticism takes place in the courts, and often results in rulings against the critics of influential officials, and in civil cases in rulings for protection of dignity. But is the judicial system independent? In other words, do the conditions exist for an essential institution that has to assure the rule of law to maintain its independence? Unfortunately, under the current judicial scheme, the courts are dependent on politicians and representatives of execu- 
tive power, both when it comes to questions of funding and when justices' career questions are being considered. ${ }^{28}$

The parliament essentially became a criminalized institution. Vital governmental decisions were adopted not in the parliament, and not even by the executive branch, but behind closed doors. In such a country, judicial institutions are threatened by government control, while legal acts limit their duty and right to protect the country from criminal groups. There are several reasons why individuals formerly tried in court or ones facing criminal charges are so anxious to be elected to the Seimas. The first reason is that a certain segment of society is thoroughly criminalized - they take advantage of the larger part of the society through criminal, illegal means. Using corrupt ties with the government, they take over material public assets and create monopolies. We see this, for instance, in the energy sector. Criminal infiltration of the government is the goal of not only the corrupt monopolist oligarchy, but of other criminal entities as well.

The story about LEO LT, which is in charge of energy, and their share transfer (almost 40 percent of their stock) to the owners of "Maxima" shows that the Parliament is governed by oligarchs. ${ }^{29}$ I can assure you that, with the emergence of LEO LT, Lithuania saw the end of oligarchy development. Billions in assets were given to a private group that controls not only energy, but the situation in the whole country. There is no longer rule of law in Lithuania, and it will take a long time for us to get out of this oligarchic system. ${ }^{30}$

\section{President Dalia Grybauskaite: Member of the European Commission, 2004-09; elected President of Lithuania 17 May 2009}

Lithuania is undergoing its peak of monopolization and oligarchization. The LEO LT enterprise was a mistake, which led Lithuania to oligarchy.... I tried to calculate how many people actually rule Lithuania. According to my calculations, the number is around a hundred. Fifteen individuals are at the very top - they govern almost all the main political parties, and there are a few people in the government and the parliament. That is all. This is how in the course of twenty years we came to stagnation. ${ }^{31}$

28 Speech by Kestutis Cilinskas, “Teisès viršenybès principo igyvendinimo problemos'; renginys tarptautinei žmogaus teisių dienai paminèti”; available at http://www3.lrs.lt/pls/inter/ w5_show?p_r=3371\&p_d=38029\&p_k=1.

29 The "Maxima" shopping network belongs to the VP (Vilniaus prekyba) group, whose subsidiary "NDX Energija" became the largest shareholder in 2003 during the privatization of Lithuania's electricity distribution network (VST). In 2007, the Lithuanian parliament and public were introduced to the "LEO LT" project, with its main goal being the erection of a new nuclear power plant-a project of the VP group and its subsidiaries. Currently, with pressure from public representatives, the dismantling of LEO LT is being debated, acknowledging the illegality of its creation.

30 "Atgimimas," "Kestutis Cilinskas: Viskas perkama ir parduodama iki paskutinio garbès lašo," Delfi.lt (16 September 2008); available at www.delfi.lt/news/daily/lithuania/article. php?id=18559213.

31 D. Grybauskaitè, "Oligarchizacijos viršūnès_Leo išlikimo nematau" (17 April 2009); available at www.bernardinai.lt/index.php?url=articles\%2F93998. 


\section{Kestutis Cilinskas}

Before the election, the magnates came to help out the poor: they offered a portion of ice cream, a bottle of beer, or one litas for a vote. ${ }^{32}$ This is both voter bribery and compensation of sorts for what was taken from the public during the disarray of the transition to a free economy. At the same time, in a very rushed manner, without letting the citizens get acquainted with, let alone discuss and decide on, such a crucial international act for the country and its citizens, the treaty establishing a constitution for Europe was ratified. One of the explanations presented to the public regarding the lack of a need for the citizens to review and vote on this treaty came from the Foreign Affairs Minister A. Valionis, who said: “... this document is important only to government institutions which, in turn, need to quickly acquire EU millions rather than study the Treaty. According to the press, the Economy Minister decided to assign those millions to one set of enterprises, while the newly appointed minister announced his intentions to give those millions to enterprises of his choosing. The principles of legitimate expectations and other principles of law give way to an almost overt war for money.",33

\section{Algimantas Matulevicius: Member of the Seimas, 2000-04 and 2004-08; member of} the Anti-Corruption Commission; member of the Economic Crime Investigation Commission; member of the National Security and Defense Committee (and committee chair from October 2006 to June 2008)

Who would have thought that after twenty years we would see legally elected criminals? That morals would become a thing of the Soviet past? That the country would be governed by liars, thieves, and bribers presenting their acts as representative of the values of Western civilization? Our country is taken over by the so-called valstybininkai clan (a term coined by journalists). It consists of individuals at the Presidential

32 The Lithuanian European Union referendum took place on 10-11 May 2003. Exclusively for this referendum the Lithuanian Parliament amended the Law on Referendum, setting an unprecedented two-day voting window in Lithuania. On the second day of the referendum it was clear that public turnout was poor and that barely 50 percent of the potential votes would be cast. At that time, Lithuanian radio and television channels announced that every voter with a sticker (given upon casting their vote) would be rewarded by Vilnius supermarket (Maxima) with a box of detergent or a bottle of beer, which cost a symbolic one cent. Word of the "I Voted" promotion spread quickly, and in a few hours' time the voters started flooding voting booths. The press announced that the promotion cost around one million $l i$ tas. The chairman of the Kaunas referendum commission, K. Serenas said, "the stickers surely caused big disarray. They were produced on a private initiative. No one led any accounting, but with the announcement of the sale at the supermarkets people flooded demanding stickers. Some of them threatened to take back their vote." See article by Arūnas Andriuškevičius, Kauno diena (12 May 2003); available at http://kauno.diena.lt/dienrastis/ kita/kaunieciai-nelauke-paskutines-minutes-8751.

33 Kestutis Cilinskas, "Teisès viršenybès principo igyvendinimo problemos," speech given in commemoration of International Human Rights Day (10 December 2004); available at http://www3.lrs.lt/pls/inter/w5_show?p_r=3371\&p_d=38029\&p_k=1. 
Palace, the government, a few agreeable politicians, judges, media representatives, special operations, and business groups. It resembles global organized crime, but this group is much more refined, of higher intellect, and thus very dangerous. They are the true rulers of Lithuania, along with business oligarchs and the media. At great personal risk, I pursued the investigation [of this group] and helped make the materials public. ${ }^{34}$ We thought this historic investigation would enable us to remove them from their offices and start the real resurrection of the state. This material was meant to have an explosive effect. But we underestimated their powers - the scope of this group's powers exceeded all expectations. They rule the President, the present government and all former ones, and they manipulate election results. ${ }^{35}$

\section{Vytautas Landsbergis: Member of the European Parliament, Chairman of the Lithuanian Constitutive Assembly}

I think there is a triangle alliance against parliamentary democracy among the Communist parties, the elite nomenklatura of the Komsomol, and the nomenklatura of the $\mathrm{KGB}$, who are waiting in the shadows for revenge and to regain their positions through the third nomenklatura - that of the Soviet judiciary. This is the triangle alliance, and it operates efficiently. The Soviet judiciary has been growing stronger as a closed circle, an authoritarian, self-forming, self-appointing body. ${ }^{36}$

\section{Arvydas Anusauskas: Chairman of the Seimas National Security and Defense Committee (elected in 2008) member of the Operational Activity Parliament Control Commission}

Times have changed, but attempts to conduct corrupt acts while ignoring public opinion remain active. So is current distrust in the Lithuanian government, which was partially inherited from the Soviet era, but was strengthened by the transition period,

34 The parliament's National Security and Defense Committee (NSGK) investigation was initiated after the death of the State Security Department (VSD) officer Vytautas Pociunas in Belarus in 2006. The investigation concluded that the officer had been sent to Lithuanian consulate in Belarus in connection with the investigation in Lithuania. The officer headed the investigation regarding corrupt ties among high officials, such as the secondary Lithuanian "Gazprom" enterprise employees, many of whom were former KGB members, with connections and influence over the highest institutions of the Lithuanian government. The investigation disclosed the highest-ranking VSD officials' connections with business groups as well as the fact that the director of the VSD was a former KGB reserve officer. The VSD investigation collected enough evidence to show VSD officials' attempts at slander using the media against the deceased officer. There were attempts to influence the progress of the investigation, as well as discredit individual members of the NSGK using media. The prosecutor's office kept issuing investigation conclusions declaring the security officer's death to be an accident. The circumstances of the officer's death were reviewed a number of times based on the court ruling; the case remains unsolved to this day.

35 Algimantas Matulevičius, “Apie demokratija ir laisvą rinką," Delfi Zinios (20 May 2009); available at www.delfi.lt/archive/article.php?id=22243500.

36 Eglè Samoškaite, "V. Landsbergis: ittaria Lietuvoje egzistuojant 'Teisejjų partiją," Delfi.lt (16 May 2009); available at www.delfi.lt/archive/article.php?id=22169098. 
which saw the failure of hopes for improved standards of living and the triumph of a corrupt administration. Even if former nomenklatura officials did not become rich businessmen while using their office and power (or information), they managed to maintain or create new informal groups based on social ties and favors. Their annual corrupt budget, according to expert assessments, exceeds 1.3 billion litas (EUR 380 million). Influential business groups can form coalitions to represent their interests, even drawing on representatives from different political parties, thus adopting laws that work against the public interest. ${ }^{37}$

Kestutis K. Girnius: Journalist, writer, political expert, correspondent for Radio Free Europe (1979-2003), director of Lithuanian and Central news

It is hard to determine the exact level of corruption in Lithuania, but its negative effect is obvious, especially in the broadest sense of its meaning-i.e., not only in terms of bribery, but also abuse of public office, and its tolerance in the highest levels of government. This year [2007], the situation deteriorated, because tolerance was more openly expressed in public, where one set of rules was shown to apply to the powerful or the so-called elite, and another to the regular public.... Apathy is constantly increased by the feeling of political powerlessness and the awareness of the judiciary's inability to curb corruption. The disability or maybe even degeneracy of our political parties is one of the main reasons why democracy is getting weaker. ${ }^{38}$

\section{A Rising Tide of Corruption}

According to the international NGO Freedom House, which observes global processes of democratization, the general Lithuanian democracy index worsened in one year from 2.21 to 2.29. This index takes into account general government, election systems, media independence, civil activity, judicial independence, and corruption. The report exposed corruption as one of the biggest problems in Lithuania, and identified the main reason as passive implementation of anti-corruption measures. Although exposures of conflicts of interest have become more open, cases of political corruption still do not reach the courts, even though they are exposed on a regular basis. The survey emphasized the lack of Lithuanian citizens' participation in public life and their minimal interest in non-governmental organization activities. It found that only every third Lithuanian resident has confidence in local municipal institutions. The reason for such mistrust is the lack of transparency and openness in disclosures of public spending. ${ }^{39}$

Lithuania is overrun by a nomenklatura oligarchy, which successfully established the Eastern model for ruling a "governed democracy." The country is ruled by political

37 Arvydas Anušauskas, "Visuomenès požiūris į korupciją. Priežastys ir pasekmès," Dešiniosios koalicijos "Vardan Lietuvos" (10 March 2008), http://vardanlietuvos.blogspot.com/2008/ 03/arvydas-anuauskas-visuomens-poiris.html.

38 Kestutis Girnius, "Demokratijos klystkeliais," Veidas (27 September 2007); available at www.veidas.1t/lt/leidinys.full/46fa2c1663b7f.

39 "Korupcija_-viena didžiausių Lietuvos problemų, teigia NVO," Londono zinios (6 September 2007); available at www.londonozinios.com/a-news-7648. 
party leaders' elite networks, which are intertwined with business moguls. The constant fighting among these groups or "clans" creates the appearance of a democracy. In fact, based on Western democratic standards, from the outside Lithuania represents a pseudo-democratic model. Lithuanian "governed democracy" differs from the Russian model only by virtue of its more subtle character; its Soviet roots are less exposed. The disobedient citizen is haunted by the ghost of unemployment and poverty, the grip of which is no less strong than the omnipotent KGB. Oligarch-owned media are carrying out "brainwashing" in the same manner as was done by the Soviet propaganda machine. ${ }^{40}$

\section{Corruption Across Cultures: A Comparison Between Post-Soviet Lithuania and Selected European Union States}

In the 1950s, Hong Kong faced endemic corruption. Its prevalence was indicated by a popular saying about people having the following choice: "go by bus" (i.e., take active part in corruption) or "run beside the bus" (be a passive observer, not getting involved in the corrupt system). However, in 1974 a politically active and resolute governor of Hong Kong established an independent anti-corruption commission, whose activity was based on three pillars: stricter criminal enforcement, increased corruption prevention efforts, and public education. In a few decades, consistent implementation of these anti-corruption measures helped to virtually completely rid Hong Kong of state government abuse. The Hong Kong model has been widely discussed, presented at conferences, analyzed, and used as an example for countries facing high levels of corruption. But the Hong Kong model is generally not applicable in other countries, as it appeared and was implemented under different historic and political circumstances, but most importantly because in almost all other cases the government is unwilling to part with its own self-created privileges. Many authors analyzing corruption emphasize the differing standards of behavior between politics and morals as the largest and most serious problem of general government. As the Polish political scientist Jan Rokita put it, "after the victory against communism, now we only need one revolution-a revolution of morals." 41

In today's Lithuanian society, informal relationships are used to help solve many personal economic questions. However, corrupt relations in the society are largely the legacy of Soviet times. Sovietologists' works show that the word "corruption" was not used during the Soviet era. Instead, the commonly used word was blat, which refers to non-monetary corrupt exchange, such as the ability to purchase goods not available in official state markets, or the ability to receive an unofficial favor. Such informal favors based on trust strengthen human ties. After "helping someone out," one can always ex-

40 Arūnas Marcinkevičius, "V. Radžvilas: Lietuvos piktžaizdės dèl demokratijos stokos," Zmones24 (11 July 2009); available at www.15min.lt/naujiena/zmones/lietuviai/3/48086/? fid $=2$.

41 Stanislovas Kairys, "Lietuvoje siauteja visas pokomunistines šalis kamuojanti epidemija," Straipsniai.lt (27 July 2004); available at www.straipsniai.lt/korupcija/puslapis/6354. 
pect reciprocal help; such favors can be called in even after a long time has passed. This informal, exchange-based relationship not only strengthens and supports family and friendship ties, but also creates various forms of mutual connections, integrates the individual into the society ("everybody does that"), and becomes part of people's identity. In post-Soviet research on the Soviet era, blat is becoming a key word in studies of daily economic relations within Soviet communities, and is seen as the most noticeable and widespread form of corruption of those times. ${ }^{42}$

With Lithuania's independence and transition to a market economy, the concept and practice of blat, as a relic of the Soviet era, took the form of corrupt relations in the new society, while the word itself disappeared from daily use. Unofficial networks and exchanges currently have little value in trying to acquire daily necessities, but they are still perceived as an inevitable practice in the social life or professional activities of every individual: in getting an education and health care, in starting and developing a business, in trying to acquire valuable information, and in politics. Reliance on informal relations continues to be a culturally legitimate practice in Lithuania, which assures the conditions for shadowy business relationships and guarantees political and financial success. The explicit act of establishing informal networks is accomplished through various leisure activities in clubs or on hunting trips, where the casual atmosphere of trust eases the conclusion of many corrupt transactions. Informal groups try to affect the legislature by using their accumulated resources, as well as by integrating with governmental institutions. The interconnection of the political elite with farreaching and criminal shadow business structures continues to support the "economy of favors" in Lithuania. ${ }^{43}$

As mentioned previously, Lithuanian citizens are very critical of the anti-corruption programs being implemented by the government. In addition, Lithuanians tend to notice corruption in their civil service, courts, and parliament more than other EU residents. At the same time, they are willing to give a bribe in efforts to get their own business moving, or in order to receive a favorable judicial decision. Such contradictions can be explained from two perspectives. Lithuanian society is used to its old tradition of "taking care of one's own business" (or, in Hong Kong parlance, "going by bus") that is, not expecting any help from the government, which is in place for the express purpose of helping solve their problems. Lithuanian society tends to ignore laws, set procedures, etc., just as was the case in Soviet times. Unfortunately, this phenomenon is widespread in the society, at all levels. According to the political scientist Kestutis Girnius, 'the Lithuanian political elite regards legal acts in terms of a 'buffet' - they

42 For an attempt to study the evolution of blat, see Donatas Brandišauskas, "Informal Networks of Corruption in Contemporary Lithuania: Between Practice and Interpretation," Lietuvos Istorijos Studijos 15 (2005); available at http://www.lis.lt/index.php?lang=EN\&id= archyvas\&TomasID=15\&ArchyvasPSL=80\&ArchyvasKiekis $=1$.

43 Ibid. 
choose, based on their taste, which laws are to their taste, and which are not. ${ }^{, 44}$ Regular citizens follow this example as well.

Thus the answer regarding the high level of corruption in Lithuania would appear to be very clear: it is simply a relic of the Soviet system, a holdover from decades lived in a blat society. However, the question of whether Lithuanians - who are in the process of building a new nation, under new conditions - regard prevalent corrupt relationships as abnormal still remains open. Many authors have analyzed the questions of morals, national culture, and corruption. Most of them associate the generally accepted moral values of a society with the spread of corruption within a country. Donatella Della Porta and Alberto Vannucci, in their essay "Corruption as a Normative System," draw a common link between governments, anti-corruption legal norms, politics, business, and the moral values of the society, by saying that where people are more (or less) honest, there we find a more (or less) honest government. ${ }^{45}$

In her analysis of corruption, Susan Rose-Ackerman views it from a cultural perspective: "These two notions of moral costs - as negative effect and as a factor affecting corruption choices - are obviously interwoven. The definition of bribes and gifts is a cultural matter, but 'culture' is dynamic and constantly changing." ${ }^{, 6}$ Such a perspective is completely correct in the analysis of corruption in Lithuania. The Soviet era had a long-lasting negative influence on civil relationships, which had an impact on the society's cultural and moral values. However, when comparing Lithuania's CPI scores with those of other countries that had been within the Soviet orbit, it is impossible to draw unequivocal conclusions. Lithuania shares twenty-seventh place with Poland on the Corruption Perceptions Index list for European Union and other West European countries. However, another former Soviet republic, Estonia, is in sixteenth place, with a relatively high 6.6 CPI score, ahead of such countries as Spain, Portugal, Malta, Italy, and Greece. Former Socialist bloc countries such as the Czech Republic, Hungary, Slovakia, and Lithuania's neighbor Latvia are also ahead of Italy and Greece according to the CPI. As a result, Lithuania's low CPI score cannot be explained away as a lingering negative effect of Soviet-era influence.

Some analysts of corruption try to find connections (larger or smaller) between corruption levels and a given country's religion (the main religions of the European coun-

44 Kestutis Girnius, "Korupcijos kultūra," Veidas (16 August 2007); available at http://verslas.banga.lt/lt/leidinys.full/46c976f5772f0.

45 "The different propensity to corruption observed in different countries has been explained, in comparative politics, among other variables, by the specific national values - be they crystallized in religion, family orientation, or confidence in the state. In such perspective the differences between countries are to be found in the substance, that is, in the sentiment of the people; where they are more (or less) honest, there we find a more (or less) honest government. The most widespread corruption, the less are its moral costs, since a growing number of politicians and businessmen internalize new codes of behavior according to which corruption is the supported norm. Political parties and business associations tend, therefore, to work as institutionalized mechanism of socialization into corruption." Della Porta and Vannucci, "Corruption as a Normative System."

46 Rose-Ackerman, Corruption and Government: Causes, Consequences, and Reform, 110. 
tries that are often compared being Protestant and Roman Catholic Christianity). Such an approach to explaining corruption is completely superficial and erroneous. Yes, the statistics do show that in Scandinavian countries, where Protestantism is dominant, corruption levels are much lower than in Catholic Italy. However, Catholic Austria has a lower level of corruption than, for example, Protestant Norway, while in (Catholic) Ireland it is the same as in (Protestant) Great Britain. For this reason, explaining the spread of corrupt relations in a society in the context of its religion is superficial in today's world. Corruption levels in a given country and its prevalent religion have no connection whatsoever. It must be the overall cultural inheritance that affects the nation's spheres of life, including religion itself. At present, when religion has any influence at all on society in European countries, its influence is drastically reduced (Europe is largely secular). Since the world is witnessing a rise in corruption levels, it is impossible to argue that religion is a determining factor of corruption levels. Even under the Law on Corruption Prevention of the Republic of Lithuania there is a statement that one of the key areas of corruption prevention is education of the public in efforts to further personal morality, which is the goal of all religions. Since 79 percent of Lithuanians declare themselves to be Catholics, a large responsibility for encouraging personal morality falls on the Catholic Church, which considers corruption to be a social evil, and emphasizes the connection between law and morals.

\section{Conclusions and Recommendations}

The prevalence of corruption in Lithuania represents a serious danger to the nation's existence. It threatens democratic rule and the stability of public institutions, human rights and the legitimacy of the legal system, social justice, and public morale. Corruption distorts competition, slows down economic development, and pushes society toward poverty. Even though corruption is not a modern phenomenon, and cannot be particularly associated with democratic political regimes, it has a considerable negative effect on the process of democratization. This negative influence on the democratic process is especially visible in post-Soviet countries, and Lithuania is not an exception, but is rather a good example of all the processes at play: from corrupt individuals' attempt to take over the country, treating the nation as though it were their private property, to the resolute fight against this corruption. Is there one common prescription for the disease of corruption? No, there is no magical, universal cure. The Hong Kong model was used as example of a successful anti-corruption struggle, but the model was not implemented in other countries due to different perceptions among countries of what acts are considered to be corrupt, to differences among national legal systems, and, finally, due to different cultures and customs. Thus, the first conclusion is that a common anti-corruption model applicable to all countries does not exist.

The process of European integration is a very important factor related to the increase in corruption levels in Europe. It is noteworthy that Lithuania's level of corruption has risen with its accession to European Union membership. Such an effect can be explained by the fact that European Union membership opened the door to access to European Union structural financing across many spheres. The enormous size of this 
funding pool - the 2007-13 structural funds budget consists of more than EUR 6.7 billion ${ }^{47}$-is an attractive source for personal profiteering among corrupt politicians and business representatives.

Another important factor that has worked to increase corrupt relations among the political elite is Lithuania's total dependence on imported natural gas from Russia, which is resold in Lithuania by an intermediary. With large funds at their disposal, business representatives can have a huge influence not only over approvals for unwanted competing economic projects, but over political processes as well.

Without a doubt one of the main causes of the spread of corruption in Lithuanian society is the lack of developed habits of good citizenship. Lithuanian citizens tend to bribe the same actors within society who can, in turn, affect the decision-making process regarding the very subject in question. Given that such societal relations are partly the result of the negative inheritance of the Soviet era, for that reason the pursuit of a broad-based education campaign within Lithuanian society is a task of such great importance, as it would inculcate resistance to such practices. Much of the responsibility for the execution of this campaign would fall on the independent media, which, while following the principles of ethics, would help create an open civil society, thus contributing to its own advancement. However, the only factor that can realistically change the current situation is the expression of political will, a resolute statement of intolerance for corrupt relations in Lithuanian society. The already mentioned Hong Kong model proved itself effective because it was accompanied by a very clear and resolute expression of political will in efforts to reduce corruption. Perfectly prepared anti-corruption models or anti-corruption legislation will not be effective in a country as long as there is no clearly defined political will to actually reduce corruption. Lithuania will become a legitimate democracy only when its citizens and political elite are ready to accept democratic values, principles, and norms - that is, when it comprehends what this type of political culture is supposed to look like.

As a result, in order to achieve the fundamental reduction of corruption in Lithuania, the following conditions are crucial:

- Officials in the highest governmental offices must clearly display the political will to fight against corruption, which would allow the actual implementation of suggested anti-corruption measures and would enable judicial institutions to execute their duties free from political influence

- Institutions controlling European Union funds must strive to ensure transparent use of these funds and, upon detection of any impropriety, should implement procedures in accordance with current law

- Swift integration of Lithuania within the Western energy system is crucial in order to decrease the nation's dependence on Russian natural gas

- The independent media must see it as a primary task to nurture good citizenship in Lithuanian society

47 See www.inovacijos.1t/index.php?787484240. 
THE QUARTERLY JOURNAL

- Since the Catholic Church has an undeniably high authority in Lithuania, it could play an important role in the development of Lithuanians' intolerance towards corruption as a moral wrong. 


\section{Bibliography}

Andriuškevičius, Arūnas. Kauno diena.

Anušauskas, Arvydas. Visuomenès požiūris i korupciją. Priežastys ir pasekmès. Dešiniosios koalicijos "Vardan Lietuvos", 2008.

Brandišauskas, Donatas. Informal Networks of Corruption in Contemporary Lithuania: Between Practice and Interpretation. Lietuvos Istorijos Studijos, 2005.

Bull, Martin J., and James L. Newell. Corruption in Contemporary Politics. New York: Palgrave Macmillan, 2003.

Cilinskas, Kestutis. 'Teisès viršenybès principo igyvendinimo problemos'; renginys tarptautinei žmogaus teisių dienai paminèti., 2005.

Cilinskas, Kestutis. Teisès viršenybès principo igyvendinimo problemos. International Human Rights Day, 2004.

Corruption Perceptions Index results for 2008. Transparency International, 2009.

Girnius, Kestutis. "Korupcijos kultūra." Veidas (2007).

Girnius, Kestutis. Demokratijos klystkeliais. Veidas, 2007.

Grybauskaitè, D.. Oligarchizacijos viršūnès-Leo išlikimo nematau., 2009.

Hodder, Rupert. How Corruption Affects Social and Economic Development: The Dark Side of Political Economy. Lewiston, NY: Edwin Mellen Press, 2007.

Holmes, Leslie. Rotten States? Corruption, Post-Communism, and Neoliberalism. Durham, NC: Duke University Press, 2006.

Kairys, Stanislovas. Lietuvoje siauteja visas pokomunistines šalis kamuojanti epidemija. Straipsniai.lt, 2004.

Karklins, Rasma. The System Made Me Do It: Corruption in Post-Communist Societies. Armonk, NY: M. E. Sharpe, 2005.

Kestutis Cilinskas: Viskas perkama ir parduodama iki paskutinio garbès lašo. Delfi.lt, 2008.

Korupcija — viena didžiausių Lietuvos problemų, teigia NVO. Londono zinios (2007).

Kotkin, Stephen, and Andras Sajo. Political Corruption in Transition, A Skeptic's Handbook. Budapest: Central European University Press, 2002.

Kraske, Marion, Christian Neef, and Jan Puhl. "Boom in Bakschikistan." Der Spiegel (2003).

Lie, Sven Arne. "Lietuvoje šlubuoja demokratija." Lietuvos zinios (2007).

Marcinkevičius, Arūnas. "V. Radžvilas: Lietuvos piktžaizdès dèl demokratijos stokos." Zmones24 (2009).

Matulevičius, Algimantas. "Apie demokratiją ir laisvą rinką." Delfi Zinios (2009). 
Miller, William L., Åse B. Grødeland, and Tatyana Y. Koshechkina. A Culture of Corruption? Coping with Government in Post-Communist Europe. Budapest: Central European University Press, 2000.

Monitoring the EU Accession Process: Corruption and Anti-corruption Policy. EU Monitoring and Advocacy Program, 2002.

Pavojingiausia-politine korupcija. Straipsniai.lt, 2005.

Piliponyte, Jolanta. "Instruments and Challenges of Corruption Diagnostics Around the World and in Lithuania." Sociologija: Mintis ir Veiksmas [Sociology: Thought and Action] 1 (2006): 101.

Porta, Donatella Della, and Alberto Vannucci. "Corruption as a Normative System." In Corruption Control in Political Life and the Quality of Democracy: A Comparative Perspective, Europe-Latin America., 2005.

Rose-Ackerman, Susan. Corruption and Government: Causes, Consequences, and Reform. Cambridge: Cambridge University Press, 1999.

Rose-Ackerman, Susan. International Handbook on the Economics of Corruption. Cheltenham, U.K.: Edward Elgar, 2006.

Samoškaité, Eglè. V. Landsbergis: itaria Lietuvoje egzistuojant 'Teisejju partiją'. Delfi.lt, 2009.

Stojimo į ES stebėsenos procesas: korupcija ir antikorupcinè politika. Vilnius: Open Society Institute, 2002. 